\title{
Atlantic overturning in decline?
}

Article

Accepted Version

Robson, J., Hodson, D., Hawkins, E. and Sutton, R. (2014) Atlantic overturning in decline? Nature Geoscience, 7 (1). pp. 2-3. ISSN 1752-0894 doi: https://doi.org/10.1038/ngeo2050 Available at https://centaur.reading.ac.uk/35580/

It is advisable to refer to the publisher's version if you intend to cite from the work. See Guidance on citing.

Published version at: http://www.nature.com/ngeo/journal/v7/n1/full/ngeo2050.html

To link to this article DOI: http://dx.doi.org/10.1038/ngeo2050

Publisher: Nature Publishing Group

All outputs in CentAUR are protected by Intellectual Property Rights law, including copyright law. Copyright and IPR is retained by the creators or other copyright holders. Terms and conditions for use of this material are defined in the End User Agreement.

\section{www.reading.ac.uk/centaur}

\section{CentAUR}

Central Archive at the University of Reading

Reading's research outputs online 


\title{
Atlantic Overturning in decline?
}

\author{
Jon Robson, Dan Hodson, Ed Hawkins, Rowan Sutton \\ NCAS-Climate, Department of Meteorology, University of Reading
}

January 3, 2014

To the Editor-

A large body of evidence identifies the Atlantic Meridional Overturning Circulation (AMOC) as an important driver of changes in climate. Changes in the AMOC have been implicated in climate events that occurred many thousands of years ago [1], and others that occurred much more recently, such as in the mid-1990s [2]. Continuous monitoring of the AMOC has only been possible since 2004 [3]. Measurements from the RAPID-MOCHA array suggest a recent decline in the AMOC [3], but at less than a decade this record is still short. Here we present evidence from other observations and a climate model which suggests that this recent measured decline is not merely a short term fluctuation but is part of a substantial reduction in the AMOC occurring on a decadal timescale.

Climate model simulations suggest that variations in the density of deep waters in the Labrador Sea are a useful predictor of changes in the AMOC (Fig 1.c and [4]). Density anomalies spread southward along the western boundary of the basin, and influence the east-west density gradient and the AMOC. Observations of density variations in the deep Labrador Sea show a large positive spike in the mid 1990s (Fig 1.a). This feature has been linked to an acceleration of the AMOC (estimated to be $\sim 3 \mathrm{~Sv}^{1}$ at $45^{\circ} \mathrm{N}$ [2]) and a rapid warming of the upper North Atlantic Ocean [2]. Subsequently, the density in this region dropped very rapidly to the extent that one dataset suggests it is now lower than at any point in the last 60 years [5] (Fig 1.a). The observed pattern of recent density change corresponds very well with the pattern associated with AMOC changes in model simulations (Fig 1b,c and [4, 6]). Based on a comparison with [2] and analysis of Fig 1.c, the observed density decrease could correspond to a reduction in the AMOC of $\sim 5-6 \mathrm{~Sv}$ (see supplementary).

The direct AMOC measurements from the RAPID-MOCHA array at $26^{\circ} \mathrm{N}$ exhibit a decline of around $-0.5 \pm 0.2 \mathrm{~Sv} \mathrm{yr}^{-1}$ over the period $2004-12$, i.e. a total decline in the $\mathrm{AMOC}$ at $26^{\circ} \mathrm{N}$ of $\sim 4 \mathrm{~Sv}$ (Fig 1.a; trend is estimated after the Ekman component has been removed and the uncertainty is quantified as $1 \sigma$; see [3] for further analysis). Without the context of the longer density record (Fig 1a), it would be hard to say whether this

\footnotetext{
${ }^{*}$ Corresponding author

${ }^{1} \mathrm{~Sv}=$ Sverdrup $=10^{6} \mathrm{~m}^{3} \mathrm{~s}^{-1}$
} 
change is a short term fluctuation or is part of a more persistent and significant event. The density record clearly suggests the latter. Furthermore, there is no sign that the density has yet ceased to decline. Given the expectation that the AMOC lags the Labrador Sea density by a few years (Fig 1.c and $[4,6]$ ), this suggests some further decline in the measured AMOC is likely.

The comparison of the observed and simulated density changes, together with the observed weakening of the AMOC at $26^{\circ} \mathrm{N}$, suggest that a substantial change in the AMOC is unfolding now. Uncertainties remain, however. In particular, the relationship between the AMOC at subpolar and subtropical latitudes is still poorly understood [7]. Indeed, some observed high latitude currents, which are thought to be related to the strength of the AMOC, have not weakened over the past decade [8]. Numerical models, including the model used in this study, are unlikely to capture adequately all the important processes, especially in the subpolar North Atlantic and Nordic Seas [9]. Finally, variables other than Labrador sea density may contribute to decadal-timescale trends in the AMOC at $26^{\circ} \mathrm{N}$ [10]. It follows that observing how these events unfold in detail offers an enormously important opportunity to test theories and models of the dynamics of the AMOC and, importantly, its role within the wider climate.

Acknowledgments We thank the RAPID science team for making the RAPID-MOCHA observations available at http://www.rapid.ac.uk/rapidmoc/. EN3 and HadISST data was downloaded from http://www.metoffice.gov.uk/hadobs/. Thanks also to Doug Smith for making the Met Office Ocean analysis available, and Len Shaffrey and the HiGEM project (http://higem.nerc.ac.uk/) for use of the HiGEM data. We also thank the anonymous reviewers for their useful suggestions. 

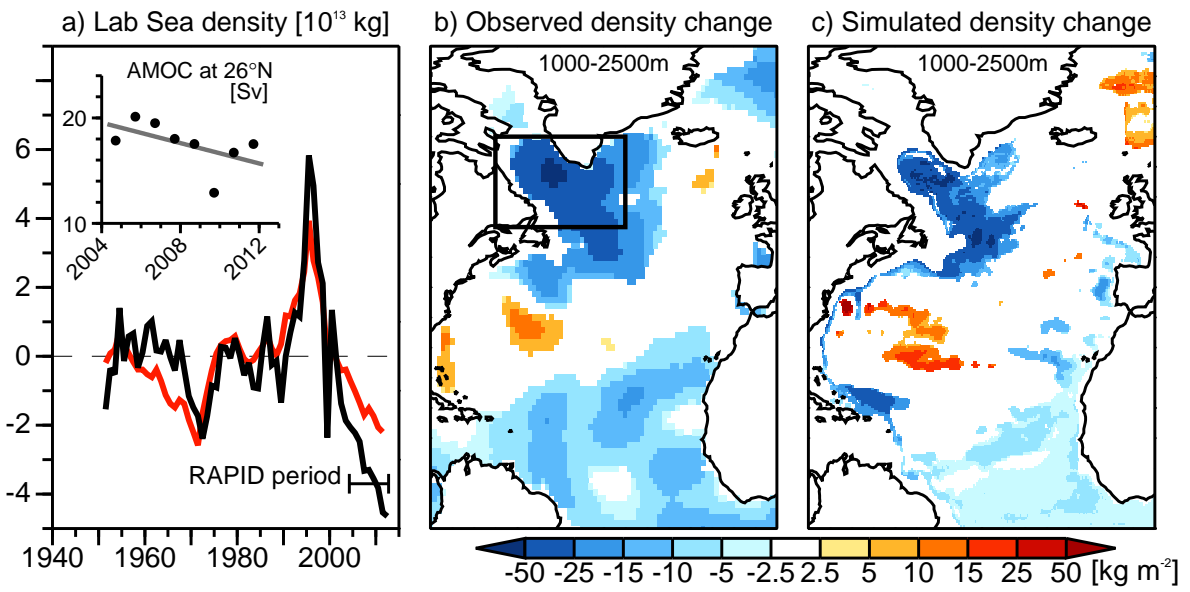

Figure 1: Labrador Sea density and the Atlantic Meridional Overturning Circulation (AMOC). (a) Observations of 1000-2500m potential density (referenced to $2000 \mathrm{~m}$; $\sigma_{2}$, relative to 1951-2006) for the EN3 [5] (black), and UK-Met Office [11] (red) ocean analyses, volume-integrated over the Labrador Sea $\left(65^{\circ} \mathrm{W}-35^{\circ} \mathrm{W}, 50^{\circ} \mathrm{N}-65^{\circ} \mathrm{N}\right.$ - shown by box on panel b) [units: $10^{13} \mathrm{~kg}$ ]. Inset is the observed annual-mean AMOC strength at $26 \mathrm{~N}$ in Sverdrups $\left[\mathrm{Sv}, 10^{6} \mathrm{~m}^{3} \mathrm{~s}^{-1}\right.$ ] [3]. (b) The spatial pattern of the observed vertically-integrated 1000-2500m density change between 1995-2000 and 2007-2012 from EN3 [units: $\mathrm{kg} \mathrm{m}^{-2}$ ]. (c) shows the scaled regression of integrated 1000-2500m density onto the AMOC at $40^{\circ} \mathrm{N}$, where the AMOC lags density by 1 year, in HiGEM [12] which is multiplied by -1 [Units: $\mathrm{kg} \mathrm{m}^{-2} \mathrm{~Sv}^{-1}$. See supplementary for further information.

\section{References}

[1] JF McManus, R Francois, J-M Gherardi, LD Keigwin, and S Brown-Leger. Collapse and rapid resumption of Atlantic meridional circulation linked to deglacial climate changes. Nature, 428(6985):834-837, 2004.

[2] J. Robson, R. Sutton, K. Lohmann, D. Smith, and M.D. Palmer. Causes of the Rapid Warming of the North Atlantic ocean in the mid 1990s. J Clim., 25, 2012.

[3] DA Smeed, G McCarthy, SA Cunningham, E Frajka-Williams, D Rayner, WE Johns, CS Meinen, MO Baringer, BI Moat, A Duchez, et al. Observed decline of the Atlantic Meridional Overturning Circulation 2004 to 2012. Ocean Science Discussions, 10(5):1619-1645, 2013.

[4] Daniel L.R. Hodson and Rowan T. Sutton. The impact of resolution on the adjustment and decadal variability of the atlantic meridional overturning circulation in a coupled climate model. Climate Dynamics, 39(12):3057-3073, 2012.

[5] B. Ingleby and M. Huddleston. Quality control of ocean temperature and salinity profiles-historical and real-time data. Journal of Marine Systems, 65(1-4):158-175, 2007.

[6] Christopher D Roberts, Freya K Garry, and Laura C Jackson. A multi-model study of sea surface temperature and sub-surface density fingerprints of the atlantic meridional overturning circulation. Journal of Climate, 2013. 
[7] M.S. Lozier, V. Roussenov, M.S.C. Reed, and R.G. Williams. Opposing decadal changes for the North Atlantic meridional overturning circulation. Nature Geoscience, 2010.

[8] Jürgen Fischer, Martin Visbeck, Rainer Zantopp, and Nuno Nunes. Interannual to decadal variability of outflow from the labrador sea. Geophysical Research Letters, $37(24), 2010$.

[9] M.W. Hecht and R.D. Smith. Towards a physical understanding of the North Atlantic: a review of model studies in an eddying regime. In Ocean Modelling in an Eddying Regime, volume 177 of Geophysical Monograph Series, pages 213-239. AGU, 2008.

[10] Cécile Cabanes, Tong Lee, and Lee-Lueng Fu. Mechanisms of interannual variations of the meridional overturning circulation of the north atlantic ocean. Journal of Physical Oceanography, 38(2):467-480, 2008.

[11] D. M. Smith and J. M. Murphy. An objective ocean temperature and salinity analysis using covariances from a global climate model. Journal of Geophysical Research, 112, 2007.

[12] L. C. Shaffrey, I. Stevens, W. A. Norton, M. J. Roberts, P. L. Vidale, J. D. Harle, A. Jrrar, D. P. Stevens, M. J. Woodage, M. E. Demory, et al. UK HiGEM: The New UK High-Resolution Global Environment Model-Model Description and Basic Evaluation. Journal of Climate, 22(8):1861-1896, 2009. 